\title{
8 NON-GOVERNMENT \\ ORGANISATIONS, \\ PEACE-BUILDING AND \\ GLOBAL NETWORKS
}

\section{Peter Ninnes}

In the first section of this book we described and explained the work of Leitana Nehan from its inception in 1992 until the end of the 'Strengthening Communities for Peace' project. I showed how it began with somewhat ad hoc work with women, focusing on humanitarian relief and awareness-raising tasks during the crisis. To this was added peace-building work, particularly in the form of 'mobilisations' of women and youth. These large meetings were supported by small grants from local and international organisations. As well as their impact on the participants, they provided Leitana Nehan with a range of organisational, fund-raising and networking experiences and contributed to the development of a cadre of volunteers to assist the founders and their spouses. The formal end of the crisis provided new opportunities for organisational learning, through attending conferences and meetings, undertaking training, and meeting with supporters and partners. In recent years, the organisation has extended its work with significant grants in partnership with overseas NGOs and government development agencies. The majority of this work has involved awareness-raising, advocacy, community development training and counselling, with a focus on women's and children's rights, prevention of violence against women, and alcohol abuse.

In the second section of the book, I have analysed the work of Leitana Nehan through a number of lenses. In Chapter 6, I explored the uses and origins of a range of discourses of gender, development 
and peace employed by Leitana Nehan. I argued that discourses are productive, because they both limit and expand the way we see ourselves and our relationships to other people and to the world. Leitana Nehan has both been exposed to, and deployed, a variety of discourses that have helped them and the participants in their programs reimagine gender relations, development and peace in Bougainville. In Chapter 7, Jonathan Makuwira described and analysed the major partnerships in which Leitana Nehan has been involved, and teased out some of the common interests that sustained those partnerships, as well the tensions that are inherent in them.

The purpose of this chapter is to analyse Leitana Nehan's work in terms of three broader sets of ideas. First I reflect on the organisation's work in the light of the literature about effective non-government organisations. I first review this literature, and then examine the extent to which Leitana Nehan's longevity and success can be attributed to the way it operates as an NGO, the effective practices it has employed, any new insights about NGO operation that Leitana Nehan reveals, and any differences between the literature and Leitana Nehan's operations that might constitute a threat to Leitana Nehan's continued work.

Second, I reflect on Leitana Nehan's work in the light of the literature on peace-building. After a brief review of relevant literature, I analyse the extent to which Leitana Nehan has conformed to the practices and approaches found to be successful elsewhere. I explore if there are any gaps in the Leitana Nehan approach, or any new insights or lessons that can be learned for peace-building work in general.

Third, and drawing on elements of the NGO and peace-building literature, I map the relationships and networks that Leitana Nehan has developed over time, as means of explaining the complexity and characteristics of the networks that have been required to undertake successful peace-building work in conflict and post-conflict contexts.

\section{EFFECTIVE NGOS}

Non-government organisations comprise a complex and multi-faceted part of civil society. In the past, they have been classified geographically as local, national and international, functionally as 
operational (providing programs) and advocacy NGOs, and in terms of their focus on human rights or development (van Tuijl 1999; Scott 2001). However, as van Tuijl (1999) observes, these distinctions are becoming blurred as NGOs recognise the links between human rights and development (see also Angeles 2003), the need to advocate for policies that support programs (see also Fitzduff and Church 2004), and as they become enmeshed in denser transnational networks. Edwards (1999) contrasts the effectiveness of development agencies on the one hand and social movements such as the environmental movement and the women's movement on the other hand. Yet many NGOs work within 'development' while being part of social movements (see, for example, Chen Jie 2001). In addition, some NGOs are becoming quasi-government organisations as they receive funding from governments and provide social services previously provided by the state (Hilhorst 2003; van Tuijl 1999)

The effectiveness of NGOs can be constrained by a number of factors outside their organisations. For example, Ewig (1999), analysing the situation in Nicaragua, observes that NGO success depended in part on the presence of elected or non-elected government officials who were sympathetic to NGOs' goals, as well as a government policy framework that allowed NGOs both to exist and flourish. In Sudan, Yongo-Bure (2003) observed that a lack of basic infrastructure - such as roads-prevented NGO programs being effectively implemented. Chen Jie (2001) argues that in Taiwan, a lack of formal diplomatic recognition has constrained the extent to which local NGOS can form links with outside organisations. Diminishing levels of official development assistance are also likely to impact on NGO operations, although some authors believe this represents an opportunity for northern and southern NGOs to transform their relationships from dependency to more substantive partnerships (Malhotra 2000) or for NGOs to embrace human rights rather than development as their dominant focus (van Tuijl 2000).

Even in contexts where policy, personnel, infrastructure and international relations issues enhance or support NGO operations, there are a number of approaches concerning the actual ways in which development NGOs operate that can be effective. Edwards (1999) 
suggests a range of effective approaches. Although his remarks are made in the context of development projects undertaken primarily by large-scale NGOs, they may well apply to a wider range of NGO operations. According to Edwards, factors contributing to the success of development projects include meeting local needs and assuming that local people have the competence to deal with these needs; ensuring beneficiaries participate at every stage; taking into account local cultural and political issues rather than simply viewing the project in terms of technical problems to be solved; finding the right mix between local and imported knowledge, while ensuring local control of the process; reducing dependency and increasing autonomy; finding a balance between material, social and institutional development; and organising in groups and linking groups together.

Edwards (1999) also emphasises three generic practices. First, local capacity needs to be strengthened so that people can identify problems and solutions and develop wide-ranging support for proposed actions. Second, outputs need to be produced which are valued by a large proportion of the population and opposed by only a few, and this depends on developing strong links between various sectors of the community. Third, 'help' needs to be in the right form. In particular, it needs to ensure local ownership and provide time and space to learn lessons and develop capacity and linkages.

\section{LEITANA NEHAN AS AN NGO}

In analysing Leitana Nehan's work, we now turn to a discussion of the extent to which Leitana Nehan has used the approaches and practices advocated by Edwards (1999). These approaches and practices were advocated in the context of development projects. Therefore, they may be more relevant to the various projects in which Leitana Nehan has engaged, from the women's and youth mobilisations to the SCP. They may be less relevant to other work Leitana Nehan has done, such as counselling, advocacy and the radio program.

1. Meeting local needs and assuming that local people have the competence to deal with these needs. The preceding chapters indicate that Leitana Nehan has responded to a wide range of local needs. During the crisis, Leitana Nehan initially met the needs of 
women and children in care centres, particularly in terms of supplying them with second-hand clothes. They also met the needs of people in other parts of Bougainville, by organising for medicines to be smuggled across the blockade. Through their mobilisations, they also met the need for people to begin to learn from and develop trust in each other, to deal with the effects of the crisis, and to begin to imagine a new way of living together. Leitana Nehan's awareness workshops have met a need to find ways to reduce violence in communities, while their counselling services have met the need for trauma counselling. The second phase of the Strengthening Communities for Peace project also began to meet the socioeconomic development needs of communities. Leitana Nehan recognised that, once communities had dealt with issues such as alcohol abuse and violence, they needed to find constructive activities for community members. SCP 2 therefore included a process of community development training and capacity-building for raising funds to meet local economic development needs. Although Edwards (1999) argues that effective NGOs need to meet local needs, Leitana Nehan shows that effective NGOs in the long term identify and respond to changing needs resulting from changing political, economic and social circumstances. The SCP project also shows the way in which Leitana Nehan has expected communities to have the competence to deal with their own issues. While Leitana Nehan provided ideas about how to conceptualise issues affecting communities, the teams working in villages and schools left it up to those communities to decide on their own solutions. There were also occasions, however, when people were not able to help themselves. In Bougainville, this was often because people were afraid or were traumatised by the war. Effective NGOs in post-conflict situations, therefore, should not only meet local needs, but also carefully assess the extent to which the conflict has impacted people's competence, that is, their ability to act. Another problem in Edwards' (1999) localneeds approach revealed by Leitana Nehan's work is that Edwards appears to assume that needs are out there in the community 
and the NGO has to identify them somehow. In Leitana Nehan's case, however, there is a much more dynamic relationship between the organisation, the community and needs, which disrupts Edwards' binary of 'communities with needs' and 'NGOs discovering needs'. First, the paid and volunteer workers in Leitana Nehan are all members of Bougainville communities. In the SCP, the members of district teams were all members of communities in those districts. Thus, to some extent, the needs of the communities were the needs of the Leitana Nehan workers. Second, communities have problems which they can identify, but what they 'need' to deal with those problems is negotiated and constructed through a variety of mechanisms, including the introduction of new ideas into communities through Leitana Nehan's workshops and the radio program.

2. Ensuring beneficiaries participate at every stage. As noted above, since Leitana Nehan workers are members of Bougainville communities, they are also beneficiaries of Leitana Nehan's programs. In addition, all of the small and large projects in which Leitana Nehan has been involved have been highly participatory. The women's and youth mobilisations were not just passive occasions in which audience members listened to speakers. Rather, they were times of sharing, singing, praying, creating, and witnessing. The awareness workshops, both before and during the SCP project, were also highly participatory. The workshops were open to all members of the community. At the same time, Edwards' (1999) idea is challenged by Leitana Nehan's post-conflict anti-violence work because the workshops were not only open to beneficiaries, such as women who would benefit from less violence, and community members who would benefit from reduced alcohol abuse, they were also open to members of the community who may have perpetrated violence or who had patriarchal ideas about gender relations.

3. Taking into account local cultural and political issues rather than simply viewing the project in terms of technical problems to be solved. It is notable that the members of Leitana Nehan have 
almost never conceptualised their work in terms of a technical problem to be solved. Indeed, one way of positioning Leitana Nehan's work is at the cutting edge of cultural, social and political change. As we saw in Chapter 6, the focus of their work is at the point where indigenous cultural practices and politics intersect with local, regional and global cultural practices and politics in the form of the church, international human rights norms and conventions, and national and provincial constitutions and laws. Therefore, Leitana Nehan's effectiveness can be attributed not just to a 'taking into account' of local culture and politics, but a dynamic, complex, informed, and committed engagement in the cultural politics of gender, development and peace in Bougainville.

4. Finding the right mix between local and imported knowledge, while ensuring local control of the process. Leitana Nehan has used a mix of local and imported knowledge. However, their work involves more than simply 'finding the right mix'; it involves actively engaging in a wide range of discussions at community and provincial levels about the composition of that mix. As a local NGO with competent and well-connected leaders, Leitana Nehan has for the most part maintained control of the process. At times, they have gratefully accepted advice from outside consultants, while ignoring other suggestions. The Leitana Nehan constitution, for example, reads in places like a template from overseas, but there are some clauses such as those to do with membership for women only, that they have not instigated. On the other hand, the SCP project at times stretched Leitana Nehan's ability to control the process. In particular, AusAID's demands that teams be implemented in all districts within a certain timeframe was not Leitana Nehan's preferred mode of operating, but needed to be followed as AusAID was funding the program.

5. Reducing dependency and increasing autonomy. In terms of human resource development, Leitana Nehan has been very effective in reducing dependence on outside expertise and developing 
their ability to run the organisation autonomously. In particular, through their years of experience, they have become adept at writing applications, reporting on project progress, and acquitting donor funds. Furthermore, they have become skilled in managing Leitana Nehan. The contribution of the late George Lesi was very important. He brought to Leitana Nehan his training and long experience in organisational management, which helped Leitana Nehan clarify workers' roles and reporting lines. On the other hand, Leitana Nehan has not been able to develop a substantial independent revenue stream. That is, their major work continues to rely on overseas funds. The SCP was funded by AusAID for four years, but once the project was complete, the workshops and other activities ceased, except in a few cases where members of volunteer teams ran occasional workshops in their home districts on a pro bono basis. Yet the SCP only covered a handful of the communities in each district, and many more communities could benefit from similar programs. In late 2004, Leitana Nehan received a new major grant from NZ Aid. However, this funding was mainly for counselling programs in the thirteen districts. Thus, while the work of Leitana Nehan continued, the scope and thrust of the work has been dictated to a large extent by what outside donors are willing to fund. These problems of project-based work are well known in the wider development community (Edwards 1999).

6. Finding a balance between material, social and institutional development. Much of Leitana Nehan's work has been conceptualised as involving psychological and spiritual development as a precursor to social and economic development. It is worth noting that in a later paper, Edwards and Sen (2000) argue that NGOs have not focused enough on changing people's hearts. Leitana Nehan, however, has taken personal change as the starting point for social and institutional change. At the same time, Leitana Nehan has not ignored those other aspects. The SPC began to deal with issues of socioeconomic development. In recent years, Leitana Nehan 
has also conducted gender awareness for police, the judiciary, nurses and teachers, thus contributing to institutional change in such areas as the treatment of rape victims in hospitals, the methods of police investigation of rape and domestic assault, and the conduct of sexual assault trials.

7. Organising in groups and linking groups together. The use of groups of various sizes and compositions has been one of the hallmarks of Leitana Nehan's work. In the beginning, Leitana Nehan was founded by a group of four friends. Although Helen had been doing some advocacy work on her own, this work began to expand once her three former school friends joined her. This original group was supported by another group of resource people that included several of their spouses. The initial mobilisations provided opportunities to articulate Leitana Nehan's ideals and purposes and to identify and recruit further volunteers. In the SCP, the team-based approach meant that Leitana Nehan's work could be spread into all districts of Bougainville. These teams were linked in two ways. First, the organisation provided project officers who had oversight of a number of teams. Second, the teams gathered together for training and program review at various times, which provided opportunities for interaction between members of different teams.

8. Strengthening local capacity. Leitana Nehan has contributed to strengthening local capacity at a number of levels. First, the founding members and their support group have expanded their skills in a wide range of areas, including management, advocacy, counselling and training of trainers. Second, more than 90 volunteers have been trained in gender awareness, violence prevention, presentation skills and workshop planning and evaluation, and many volunteer counsellors have been trained. Third, the teams themselves have trained people in the villages in terms of gender awareness, violence against women, alcohol abuse, and to undertake community mapping, identify their needs, and source funds to undertake programs of importance to them. In Leitana Nehan's case, the capacity that has been strengthened is not just in terms of technical 
skills. Rather, Leitana Nehan's work has enhanced people's awareness of, and ability to conceptualise and address issues pertaining to gender, violence, rights and a range of other relevant social problems. In other words, it has been a process of both raising awareness and building capacity.

9. Producing valued outputs and developing strong links between various sectors of the community. There are many pieces of evidence that the work undertaken by Leitana Nehan is valued by various sectors in the community, and only a few examples are mentioned here. First, one long-standing volunteer reported that the personality integration workshops were a 'hit' with young people because they improved their self-esteem. Second, some of the team members reported that requests for involvement in SCP came after community members heard the Leitana Nehan radio program. Third, in some places, community members have asked for further workshops after the SCP program was completed. Fourth, people often saw the results of Leitana Nehan's work in other communities, such as the reduction in homebrew production and consumption, and wanted similar changes for themselves. At the same time, some team members reported resistance to their work. In one of the patrilineal communities in Bougainville, the team leader reported that men in the community had accused the Leitana Nehan team of trying to change custom when they spoke out against wife-beating. The same men also were offended by female team members 'telling men what to do'. Another team, working in one of the districts near the former copper mine, were met with suspicion in two communities. The team leader believed that the communities thought that Leitana Nehan had a hidden agenda of getting the mine operational again.

10. 'Help' is provided and received that ensures local ownership and provides time and space to learn lessons and develop capacity and linkages. The 'help' that Leitana Nehan has received from outside organisations has for the most part ensured that Leitana Nehan has had substantial control and ownership of their programs. In the early days, the small grants of several thousand 
kina for organising mobilisations came with few strings attached. Leitana Nehan was free to organise the meetings in ways that they believed would be effective. Later large grants, such as the two phases of the SCP, had more strings attached in terms of reporting requirements and the timeframe in which the projects had to be completed. On the other hand, major components of the SCP projects were based on activities and strategies that Leitana Nehan had used in the past, and which were deemed to be suitable to the needs and contexts of Bougainville communities. It should also be noted that these major projects were only funded after Leitana Nehan had spent eight years learning lessons and developing its capacity and links to outside organisations. In this regard, Leitana Nehan provides a close fit with this aspect of Edwards' (1999) theory of effective NGO practices. The characteristics and extent of the linkages that Leitana Nehan has developed are discussed in more detail in the final section of this chapter.

\section{EFFECTIVE PEACE-BUILDING}

Whereas peace-making is the process of bringing armed conflict to an end, peace-building involves creating a set of conditions where people are not inclined to resort to violence as a means of solving their problems (Brand-Jacobsen and Jacobsen 2000). Lederach (1997) identifies three major tasks of peace-building in post-conflict recovery, namely, rebuilding infrastructure, re-establishing social institutions, and reconciliation. Although Lederach's scenario is an ideal-type, Rigby (2001) identifies purposefully forgetting, pursuing justice, truth-telling, and compensation and reparation as alternative or additional processes to reconciliation. Spence (1999) notes the need for social, political and economic reconstruction, and the repatriation and demobilisation of combatants. Harris (1999) adds a further task - the construction of a new, peaceful vision for society. This vision of society needs to address the underlying causes of the conflict, which are often grounded in inequity, poverty, or other forms of structural violence (Harris and Lewis 1999a; see also Rigby 2001; Junne and Verkoren 2005). Furthermore, armed conflict is traumatic, 
and part of the reconciliation process involves dealing with a wide range of psychological issues that arise (Lewis 1999a).

In terms of NGOs' role in peace-building, Harris and Lewis (1999b) argue that, although many international NGOs play prominent roles in post-conflict recovery, these are not unproblematic. International NGOs can be flexible, responsive and able to work with local partners, while advocating for marginalised groups. Many, however, run programs without accountability and evaluation, are linked to government aid agencies in their home countries, compete with each other for funds, and fail to coordinate efforts with other organisations. Furthermore, they often represent the local people as helpless and childlike. International NGOs traditionally focus on reconstruction, but they can also contribute in human rights work, trauma recovery, conflict resolution, policy advocacy and so on, as well as helping local NGOs develop and strengthen their capacities (Harris and Lewis 1999b). Spence (1999) adds that International NGOs and local NGOs need to use local knowledge, avoid topdown approaches, use participatory approaches, and act as advocates against injustice. Of relevance here, Lewis (1999b) notes the importance of dealing with sexual assault issues as part of post-conflict reconstruction and the dangers of using culturally sensitive approaches to gender relations that often reproduce patriarchal relations and, by limiting the involvement of women, reduce the extent to which human resources for peace and development are established.

Reviewing two decades of peace-building work in a wide range of countries and contexts, Lederach (2005) has identified four practices that he argues comprise the components of a 'moral imagination' and that are essential for peace-building work. The first of these is relationships. Peace-building, Lederach argues, 'must experience, envision and give birth to the [new] web of relationships' (2005:34). This involves developing relationships, networking, and acknowledging interdependence and mutuality. These new webs require humility and self-recognition: the builders of the webs need to see themselves as part of the previous, destructive pattern and take responsibility for changing it. 
Second, peace-builders need to have and nurture 'paradoxical curiosity' (Lederach 2005:35). Many conflicts are conceptualised in terms of 'us and them' dualisms. The moral imagination refuses simplistic binaries or polarities. Lederach uses 'paradox' here in the sense of that which is outside that normally considered to be true. By curiosity, Lederach (2005) means careful inquiry that goes beyond established meanings. Paradoxical curiosity then 'approaches social realities with an abiding respect for complexity, a refusal to fall prey to the pressures of forced dualistic categories of truth, and an inquisitiveness about what may hold together seemingly contradictory social energies in a greater whole' (2005:36). On the one hand paradoxical curiosity takes people and their experiences at face value; on the other hand it explores the deeper meanings of what people value and their experiences. It suspends value judgements. It views complexity as a friend out of which new possibilities will become apparent (2005).

Third, peace builders need to employ creativity that 'moves beyond what exists toward something new and unexpected while rising from and speaking to the everyday' (Lederach 2005:38). Furthermore, in the peace-building process, space needs to be provided for creative acts to occur. Lederach also adds that peace-building can include input from groups in the community whose work involves creativity, such as artists.

Finally, peace-builders need to be willing to take risks (Lederach 2005). These risks have no guarantee of safety or success. In violent conflict, peace is a mystery and therefore it takes a risk to move in the direction of peace. According to Lederach (2005:163), 'risk accepts vulnerability and lets go of the need to a priori control the process or the outcomes of human affairs'. Risk in peace-building particularly involves seeking 'constructive engagement with those people and things we least understand and most fear' (2005:173).

\section{LEITANA NEHAN AS PEACE-BUILDER}

Leitana Nehan has contributed to many tasks indentified above as peace-building; in particular, it has contributed to providing a new 
vision for peace, psychological recovery, reconciliation, the reestablishment and re-thinking of social institutions, especially families and villages, but also political institutions, through its advocacy for women's and children's rights to be recognised at the provincial level. As a local NGO, Leitana Nehan has avoided many of the pitfalls encountered by international NGOs undertaking peace-building work. In this section of the chapter, however, I want to explore Leitana Nehan's work through the lens of Lederach's four principles of peacebuilding and discuss the extent to which Leitana Nehan's effectiveness as a peace-builder can be explained in terms of those four principles.

1. Developing relationships and networks across boundaries, taking responsibility and acknowledging mutuality. The extent and characteristics of the relationships and networks that Leitana Nehan has developed are explored in detail in the last section of this chapter. Here it is important to make a number of points. First, as a local NGO, Leitana Nehan at its founding already had a wide set of relationships and networks in place. As noted in earlier chapters, Leitana Nehan's founders had a range of affiliations in the Provincial Council of Women, in the Catholic Women's Association, in the chiefly social system, among their school alumni and so on. They also had networks resulting from their pre-crisis employment as teachers, welfare workers and accountants. Furthermore, their support group also had contacts, such as through the local business community. During the crisis, and in the post-conflict period, Leitana Nehan has developed a wide range of contacts in the local, national and international NGO community, among politicians, civil servants, and with other denominations. The relationships that they have built across gender and political boundaries are of major importance to their peace building efforts. The fact that they have included both men and women in their teams has indicated their willingness to make gender equity a community-wide issue and effort. The fact that they have included ex-combatants from all sides of the conflict, as well as people from communities who did not take sides, indicates their willingness to establish relationships across previously impenetrable barriers. Boundary crossing was also exhibited in 
the inclusive nature of the large youth mobilisations held in the late 1990s (see Chapter 3), which brought together youth from all the major Christian denominations in Bougainville. Some boundaries have been more difficult to cross than others. From time to time there are tensions between NGOs on Bougainville, and some of these fractures occur along lines created during the conflict. Leitana Nehan has also been prominent in its willingness to take responsibility for peace-building. One of the rationales for the founding of Leitana Nehan was the realisation that 'we must help ourselves' (Chapter 2). Furthermore, their training and deployment of ex-combatants as volunteers provides opportunities for these groups to take responsibility for building peace. The Leitana Nehan founders also acknowledge mutuality. As noted in Chapter 6, Leitana Nehan workers and founders often conceptualise peace as a process that begins through an acknowledgement of one's own need to change.

2. Exhibiting and practising paradoxical curiosity, including a refusal to employ binaries, breaking out of the mould and entertaining paradoxes. Leitana Nehan displays these attributes in a number of ways. For example, the ways in which Leitana Nehan conceptualises gender, explored in Chapter 6, represent a complex constellation of liberal, cultural and radical cultural ideas which, it might be argued, are mutually exclusive but which Leitana Nehan employs simultaneously. This approach allows them to reject binaries which view women's and men's interests as diametrically opposed, and instead provides a context in which unique contributions are celebrated and affirmed while recognising the need for all community members to contribute to gender work. The wide extent of Leitana Nehan's networks, discussed below, indicates the willingness of the Leitana Nehan leaders to take at face value people who are willing to contribute to their work. At the same time, Leitana Nehan does not necessarily subscribe to an identical set of values with all the people with whom they work and collaborate. Their engagement with the Catholic church is a prime example. The church and Leitana Nehan have many values in common, but certain aspects 
of women's rights, for example, are problematic. Nevertheless, Leitana Nehan leaders are able to accommodate and work with complex relationships such as these.

3. Creatively going beyond the normal order of things. Many aspects of Leitana Nehan's work reflect a creative approach to building peace in Bougainville that goes beyond the normal order of things. Leitana Nehan employs both men and women to address issues of gender; it employs both ex-combatants and non-combatants to address issues of non-violence; and it employs former producers and consumers of homebrew to educate people about the dangers of alcohol. The leaders of Leitana Nehan have also been creative in the way they have been able to seize opportunities as they arise. The visit by a Save the Children representative, described in Chapter 2, was seized as a way of (creatively) distributing medicines in Bougainville. The suspension of regulations limiting public gatherings in 1994 was seized as an opportunity to mobilise women for peace and hold the Bougainville Reunion at Hahela. Smuggling the video of that event out of the country was also a creative act. Employing a man, the late George Lesi, as deputy executive director of a women's agency may also seem beyond the normal order of things, but he brought a commitment to the issues and crucial managerial skills to the organisation. The Silent March in Buka (see Chapter 3) was creatively timed to coincide with a visit to Buka by the prime minister of Papua New Guinea and the accompanying media contingent. The use of deliberately vague statements about the goals of the November 1997 youth mobilisation (see Chapter 3) was also a creative act. In addition to creative thinking and strategising, Leitana Nehan has sometimes used creative methods in its programs; the Hihatuts Theatre Troupe (see Chapter 4) is an excellent example. Other examples include the use of story, song, and poetry-writing in youth mobilisations (Chapter 3), and the use of locally created visual aids such as posters in awareness workshops.

4. Taking risks. Letian Nehan's work, described in the previous chapters, demonstrates Lederach's (2005) idea that effective peace- 
building involves taking risks. In the case of Leitana Nehan, these risks have taken a number of forms. First, moving back to Buka in late 1990 after the return of the PNGDF represented a risk given the armed forces' lack of discipline. Advising women about safety issues was also risky. Distributing clothes and medicines to people around Bougainville was risky, as was holding the Silent March in 1995. Delivering clothes to Sam Kauona in the bush and flying in to meet women behind the blockade were also risky endeavours. Even travelling to Port Moresby, as most Leitana Nehan workers and volunteers need to do in order to travel overseas or to other parts of Papua New Guinea, was risky, as Helen discovered when she was threatened at the airport there (see Chapter 3). Previous chapters described many other examples of Leitana Nehan staff risking physical harm to carry out their work. In addition to physical harm, Leitana Nehan has been willing to take risks in terms of both its initial establishment and its subsequent development of contacts and supporters. For example, the initial break with the Provincial Council of Women in 1995 risked alienating potential allies and represented a major move into the unknown. Becoming an organisation that worked with a wide array of groups locally, nationally and internationally, including in the case of Leitana Nehan, men, ex-combatants, academics, consultants, project managers and so on is also risky, because such groups and individuals may not understand or entirely share the values and goals of the organisation. Furthermore, there is a risk that the greater access to funds or ideas may allow outside groups to exert undue control over the organisation's direction. In Lederach's (2005) terms, Leitana Nehan and its leaders have in fact been willing to take risks that expose their vulnerability and that present the possibility of not being able to control proceedings completely. In addition, they have constructively engaged with actors or members of groups that have not always acted in the best interests of women or Bougainvilleans in other contexts. Such inclusive, risky and paradoxical approaches are a major reason for Leitana Nehan's success as a peace-building organisation. 


\section{THE NETWORKED NGO}

One common focus in the literature on effective NGOs and effective peace-building reviewed is the importance of creating linkages, relationships and networks. In the case of Leitana Nehan, Jonathan Makuwira explored one aspect of Leitana Nehan's network in the previous chapter by examining its partnership with IWDA and AusAID. But, like many effective local NGOs, Leitana Nehan is part of a wider network, and a component of a worldwide transnational advocacy movement concerned with the promotion of women's rights.

Many development theorists and commentators employ economic definitions of globalisation (for example, Wanyeki 2004; Kelly 2004; Makhlouf 2004). As Desai (2004) observes, however, globalisation has space, time and cognitive dimensions. In terms of the latter, it is more than economic ideas that circulate. Cornwall and NyamuMusembi (2004), for example, reveal the antecedents of rights-based approaches to development, their transfer from local/national to global forums, and their various manifestations in different places and among different development actors. Globalisation can therefore be conceived more broadly than being just the worldwide circulation of particular economic policies and their concomitant cultural forms. Globalisation also involves the worldwide circulation of ideas about rights, democracy, education, peace, activism, strategies, philsosophies and so on, and studies in globalisation rightly include studies of social movements and transnational advocacy. It is pertinent, therefore, to view the growth and development of a local grassroots NGO such as Leitana Nehan as a positive aspect of the phenomenon of globalisation, and it is worth exploring how Leitana Nehan has become embedded in a web of networks.

Henry et al. (2004) argue that networks are transnational agents of development. They assert that networks arise primarily in response to the challenges of global capital and information and communication technologies, and that networks help to improve an organisation's competitive advantage. In the case of Leitana Nehan, its networks developed as a result of a need to promote peace-building in Bougainville, and the organisation was not so much interested in competitive advantage as in finding ways to achieve their goals. Other 
aspects of the ideas of Henry et al. (2004) about networks are, however, worth employing here as a lens through which to analyse Leitana Nehan's work. First, they argue that understanding networks involves understanding the power dynamics involved, and the inclusions and exclusions that occur in the process of establishing networks. Second, Henry et al. (2004) advocate the examination of how networks are established and maintained, and the commonalities and contestations of values inherent in and influencing the networks. Below, I explore these two dimensions of the networks that Leitana Nehan has established, after first attempting to map their development over the three periods of Leitana Nehan's history described in Chapters 2-5.

\section{LEITANA NEHAN'S NETWORKS}

Drawing on material in previous chapters of this book, I now attempt to show how the characteristics and dynamics of the networks in which Leitana Nehan is enmeshed have developed and changed over time. Some social network analysts attempt to measure the strength of relationships in social networks (Wasserman and Pattison 2004; Freeman 2005), but the descriptions provided in the previous chapters indicate the extent to which Leitana Nehan has been involved with various actors. Therefore, in this analysis I trace the changes and continuities in the types of groups with which Leitana Nehan has been involved, the geographical positioning of the group, and the kind of relationship that Leitana Nehan had with each group. I identify four broad groups: non-government organisations, including local, national, regional and international; governments, including local, provincial, national (PNG) and international (for example, Australia, Britain), as well as bodies comprising personnel from regional nations (for example, the Truce Monitoring Group); multilateral organisations (for example, UN bodies); and other social institutions (family, church, chiefly system). I use four geographical categories: Bougainville (including all of the province of Bougainville); Papua New Guinea (excluding Bougainville); the region (including Australia, New Zealand, the South Pacific islands) and the rest of the world. I group relationships into four broad kinds. I recognise that relationships can be multidimensional, and I attempt to identify 
the major kind of relationship that occurred between Leitana Nehan and the other groups. The relationships are

- providing Leitana Nehan with funding for programs for community members

- providing Leitana Nehan staff or volunteers with funding for training or directly providing training or professional development, including conference attendance and study tours

- providing logistical or material support, such as equipment, transport, or personnel for joint delivery of programs

- moral support and legitimacy, such as the support provided by families and other women's organisations or the legitimacy afforded by prizes.

Furthermore, I compare these relationships across the three periods of Leitana Nehan's history that I employed in Chapters 2-5, namely, 1992-95 (pre Beijing); 1995-99; and 2000-04.

In the period 1992-95, most of the components of Leitana Nehan's network were within Bougainville. Given that the crisis was at its peak, this is not surprising. The network within Bougainville comprised family, friends, the church and the chiefly system, which provided moral support and legitimacy, as well as logistical and material support. Some logistical support and professional development was obtained through the provincial government, and its affiliate, the Provincial Council of Women. The network comprised some links with other parts of Papua New Guinea, including the Rabaul Diocese of the Catholic Church, which assisted with supplies of second-hand clothes; the BEST group, who provided training for local women; and the Goroka office of SCF, which supplied medicines for distribution. In the region, Leitana Nehan linked with two Australian NGOs, namely IWDA and CAA, which provided training and funding.

In the period 1995-99, Leitana Nehan's network expanded considerably in particular directions, especially once the ceasefire came into effect in 1997. The cessation of hostilities allowed greater levels of communication, although there continued to be risks involved. Most of the components of the network within Bougainville remained intact. Leitana Nehan began to make more contact with 
other Bougainville-based NGOs, particularly in terms of liaison and exchange of ideas, which enhanced the legitimacy of their work. The organisation also began to have contacts with a much wider range of NGOs in Australia, New Zealand and the Pacific, as well as the wider world. These included Community Aid Abroad, IWDA, Oxfam NZ, Pacific Women Against Violence Network, Fiji Women's Crisis Centre, the Asian and Pacific Development Centre, World Vision, Caritas, Oxfam, SCF, and the YWCA. These connections mainly involved the provision to Leitana Nehan of funding and training or professional development. In addition to this extensive expansion of Leitana Nehan's NGO network, the organisation made links with a much wider range of governments and government bodies in this time. In Bougainville, it continued to have contacts with the Bougainville provincial governments, and also made contact with the BRA at one stage. In Papua New Guinea, it had dealings with the Division of Health, and commenced its work with the National Broadcasting Corporation. The organisation had dealings with the Truce Monitoring Group and its successor, the Peace Monitoring Group, as well as with AusAID and the British High Commission. Although Leitana Nehan continued to have contacts with the Catholic church in both Bougainville and the remainder of Papua New Guinea, there appear to have been few, if any, links with church bodies outside Papua New Guinea-in contrast to the situation with its contacts with NGOs and governments. Furthermore, in this period, there were few, if any, formal links with multilateral organisations such as UNICEF, UNESCO, WHO or other UN bodies.

From 2000 onwards, during the Strengthening Communities for Peace project, Leitana Nehan continued to expand its networks on Bougainville and beyond. Its networks among chiefs, the local churches, and local NGOs remained intact, and their relations with these groups were of a similar kind. New links developed with NGOs, governments and international organisations in various parts of the world. However, three major changes in the type and characteristics of Leitana Nehan's positioning stand out. First, its links with outside NGOs became more intently focused on its relationship with IWDA, because of the partnership with that organisation (described in Chapters 4, 5 and 7). 
This was inevitable because of the substantial size of the Strengthening Communities for Peace project, which was on a scope and scale well beyond any previous work conducted by Leitana Nehan. As Jonathan Makuwira noted in Chapter 7, the nature of the relationship between these two NGOs shifted over time, from one of client-beneficiary to one of relative mutuality, as the skills, experience and knowledge of Leitana Nehan leaders expanded.

Second, the nature of the relationship between Leitana Nehan and local and national NGOs shifted in this period. Initial contacts, such as with the Bougainville Women for Peace and Freedom, involved sharing experiences and establishing relationships (Chapter 3). Later, Leitana Nehan began offering some workshops jointly with other local NGOs. Starting in 2001, the executive director of Leitana Nehan began acting as a consultant to, or providing training for, other national, regional and international NGOs or funding bodies, such as NZ Aid, the Papua New Guinea Community Development Scheme, World Vision, and the Fiji Women's Crisis Centre. Whereas Leitana Nehan had in the past been a recipient of funds and other forms of support from such organisations, the organisation was now able to offer services to these organisations, based on experiences it had built up over a decade or more of community-based peace and development work.

The third notable change in the nature and characteristics of Leitana Nehan's networks in the period from 2000 concerned its relationship with Bougainville government bodies. In 1999, a single Bougainville provincial government was formed, replacing the Bougainville Interim Government and the Bougainville Transitional Government. Along with the continuation of the ceasefire, this allowed the re-establishment of various government functions such as police, the judiciary, the health system, the school system and so on. As a result, new opportunities arose for Leitana Nehan to expand its networks to connect with these groups. As was the case with the changes in Leitana Nehan's relationships with other NGOs, the new relationships with these government bodies involved more giving than receiving, particularly in the form of gender awareness and conflict transformation training for nurses, police, magistrates, and teachers. 